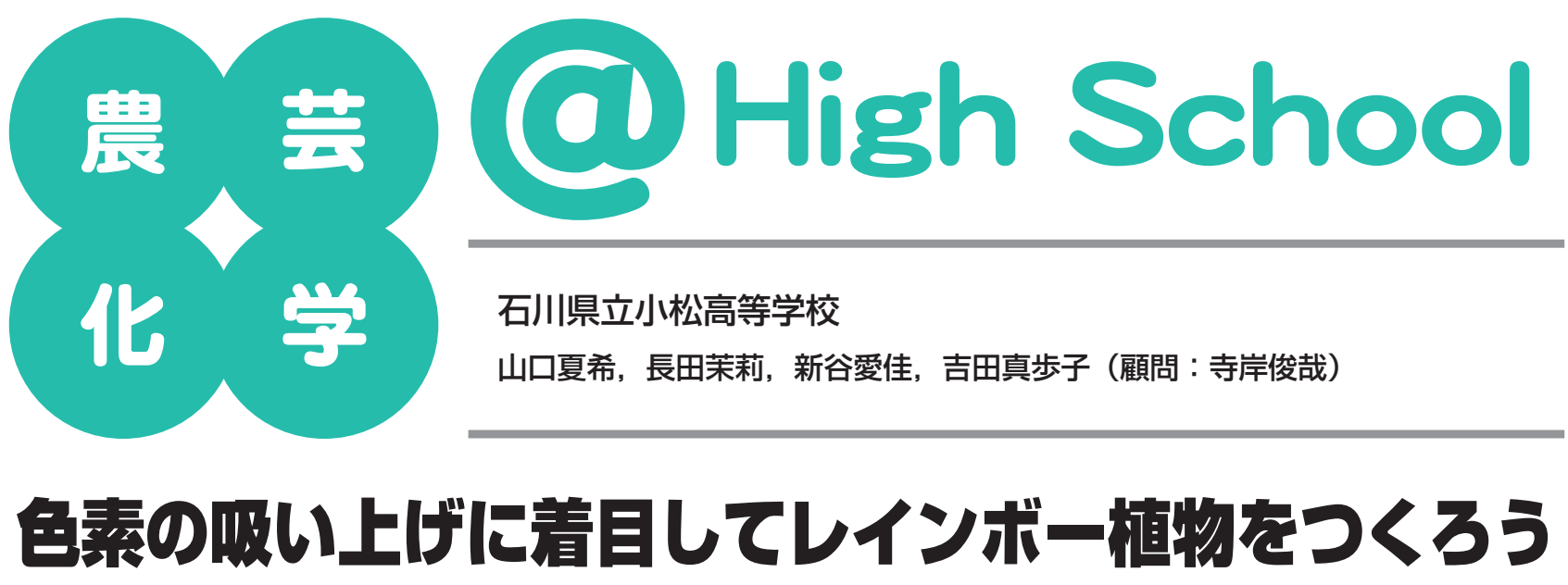

本研究は, 日本農芸化学会 2013 年度大会（開催地：東北大 学）での「ジュニア農芸化学会」において発表され，銅賞を 表彰された。 レインボー植物は, 白い花の花弁を染料で着色 して虹色に染め分けた一種の造花であるが，花弁ごとに異な る色で均一に染め分けることは難しいとされる. 発表者たち は, 植物の吸水・蒸散と花弁の染まり方との関係を調べると ともに, 花茎から花につながる維管束構造を丹念に観察する ことで, 花弁が均一に染色される条件および花弁ごとに染め 分ける方法を追求しており, 得られた結果は非常に興味深い ものとなっている.

\section{本研究の目的, 方法および結果*1}

【目的】レインボー植物が「花弁の均一な染色」と「花 弁の染め分け」という 2 つ技術により成り立つと考 え，「花弁が均一に染まる環境条件の発見」と，「花弁の 染め分け方の確立」を目的とした。

\section{【実験方法】}

実験 1 ：花弁が均一に染まる条件の検証

人工気象器内 $\left(\right.$ 約 $\left.22^{\circ} \mathrm{C}\right)$, 実験室内 $\left(\right.$ 約 $\left.16^{\circ} \mathrm{C}\right)$, 廊下 （約 $12^{\circ} \mathrm{C} ）$ のつの実験区でそれぞれ湿度 $100 \%$ の環境と シリカゲルを敷いて乾燥させた環境をつくった。そして ガーベラの花に切り花着色剂を吸わせ, 各実験区におけ る蒸散量と吸水量を計測し，花弁の染まり方との関係を 観察した。 その際, 花弁がどれだけ蒸散あるいは吸水し たかを示す指標としてそれぞれ吸水率，蒸散率を以下の ように定義した。

$$
\text { 吸水率 }=\frac{\text { 吸水量 }}{\text { 生重量 }} \text { 蒸散率 }=\frac{\text { 蒸散量 }}{\text { 水量 }}
$$

*1講演要旨集とポスターを部分的に改変転載.
実験 2 : 花弁の染色パターンと維管束の形状の比較

ガーベラの花茥を4分割し, それぞれの切断面を異な る色の切り花着色剤に浸し, 吸水させた。十分吸水させ た後，花茎の根元から花に向かってさまざまな位置にお ける花茎の切片を作成し, 維管束の染色の様子を観察し た．また維管束の染色の様子が花弁の染色パターンに反 映しているかどうか調べた。

さらにシンビジウムの花茎をガーベラと同様に 4 分割 し，それぞれを異なる色の切り花着色剂に浸した後，花 弁直下の維管束の染色の様子を観察した。 そして花弁の 染色パターンにどのように反映されているか調べた。

\section{【結果と考察】}

\section{実験 1 :}

吸水率と蒸散率は, 湿度が高い環境よりも乾燥した環 境で高い傾向が見られた。 また乾燥した環境では, 温度 が高いほど吸水率が高かった（表1）.

蒸散率と吸水率を指標にして，さまざまな条件下で染 色を行い花弁の染色の度合いを比較した。乾燥・低温の 蒸散率が高く吸水率が低い条件では，均一に染まらず， 花弁の先端が濃く染まった（図1d)。蒸散率が高い条件 では，花弁の先端から活発に水分が放出されていくこと で, 着色剂の色素が花弁の先端に蓄積され, 花弁の染色 パターンに濃淡が生じたと考えられる．また乾燥・高温

表1・さまざまな環境下における吸水率·蒸散率

\begin{tabular}{|c|c|c|c|c|}
\hline & & 約 $12^{\circ} \mathrm{C}$ & 約 $16^{\circ} \mathrm{C}$ & 約 $22^{\circ} \mathrm{C}$ \\
\hline \multirow{2}{*}{ 乾燥 } & 吸水率 & 0.153 & 0.125 & 0.297 \\
\hline & 蒸散率 & 1.360 & 1.132 & 1.094 \\
\hline \multirow{2}{*}{ 多湿 } & 吸水率 & 0.055 & 0.084 & 0.058 \\
\hline & 蒸散率 & 0.153 & 0.334 & 0.067 \\
\hline
\end{tabular}



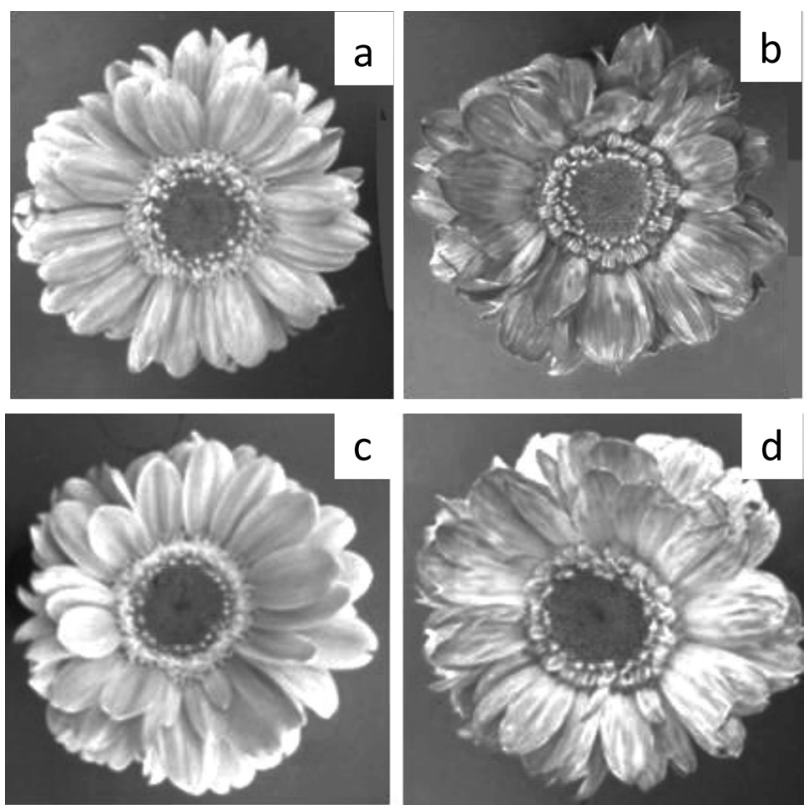

図 1 -さまざまな環境下におけるガーべラ花弁の染色度合い a. 多湿 - 高温, b. 乾燥 - 高温, c. 多湿 - 低温, d. 乾燥 - 低温.

の蒸散率が高く吸水率が高い条件では, 乾燥・低温条件 下に比べて花弁が濃く染まるものの，花弁に白い部分が 残った（図1b)。これは高温条件下では吸水が速く，花 弁の細胞と染色液の接触時間が短いために染色むらが生 じたと思われる。一方, 湿度が高く蒸散率が低い条件で は花弁は均一に染まった。 また温度が高くなるにつれて 花弁は濃く染まるが，乾燥条件下で見られたような染色 むらは生じなかった（図1a，c）。これらの結果から花弁 を均一に染色するためには多湿の条件がよく，また温度 が高いほど花弁は濃く染まることが明らかとなった。

実験 2 :

花弁の染め分けは，花弁につながる維管束を分割し， それらを異なる色の切り花着色剂に浸すことで可能であ り，市販のレインボーローズも同様の処理を行っている
とされる，そこでガーベラの維管束を 4 等分し，各々を 異なる染色液に浸したところ, 予想通り花弁は 4 色に染 め分けられた。しかしそれぞれの色の面積比は 4 等分に ならず，しかも花弁によって複数の色が混じっているよ うに見える筒所があった。このような結果の原因として 花茎下部の維管束が上部の花弁まで真っ直ぐにつながっ ておらず，途中で維管束が分岐・合流したり，配置が変 化したりすることで，花弁の染色パターンに影響が出て いる可能性が考えられた。 そこで花茎下部から花に向 かってさまざまな位置の横断切片を作成し，維管束の染 色の様子を観察したところ，花茎の上部に向かうにつれ ていくつかの隣接した維管束同士が合わさって見える部 位が観察された。しかし維管束同士が近接しているため に異なる染色液が混じったように見えるのか, 実際に維 管束中で染色液が混じっているのかどうかまではわから なかった。

そこで花序が一つであるシンビジウムの花を用いて ガーベラと同様の処理を行い, 花直下の維管束の染色の 様子と花弁の染色パターンを詳細に調べた。その結果, 花直下で6力所の維管束の集合体が見られ，それぞれの 集合体の染色パターンとその上部の花弁の染色パターン が対応していた（図2）。これらの結果から，花直下の 維管束の集合体ごとに切り分け染色することができれ ば，各花弁を染め分けることが可能になると考えられ た。

\section{本研究の意義と展望}

維管束を切り分けて花弁を染め分ける方法はよく知ら れているが，花弁ごとに異なる色にむらなく染め分ける ことは難しいとされている。現在この手法が確立してい るのは, オランダの会社が販売しているレインボーロー ズ（特定のバラの品種を染め分けたもの）だけであり，

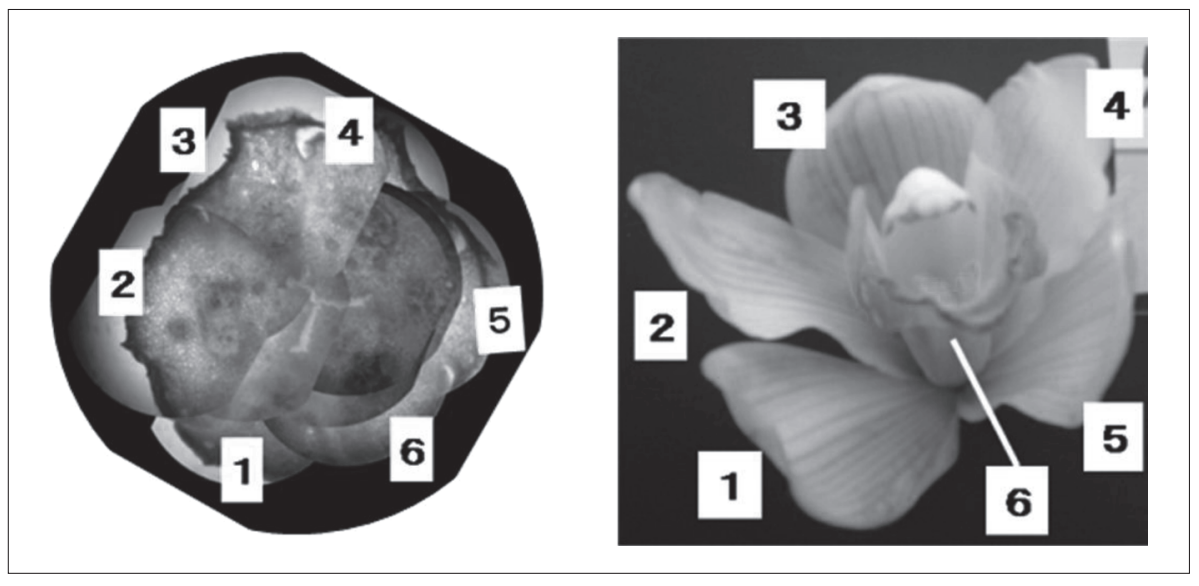

図 2 ・ シンビジウムの花直下の維管 束の染色パターン（左図）と花弁の 染色パターン（右図）

1 ～6の番号はそれぞれ対応する花弁 を示す. 


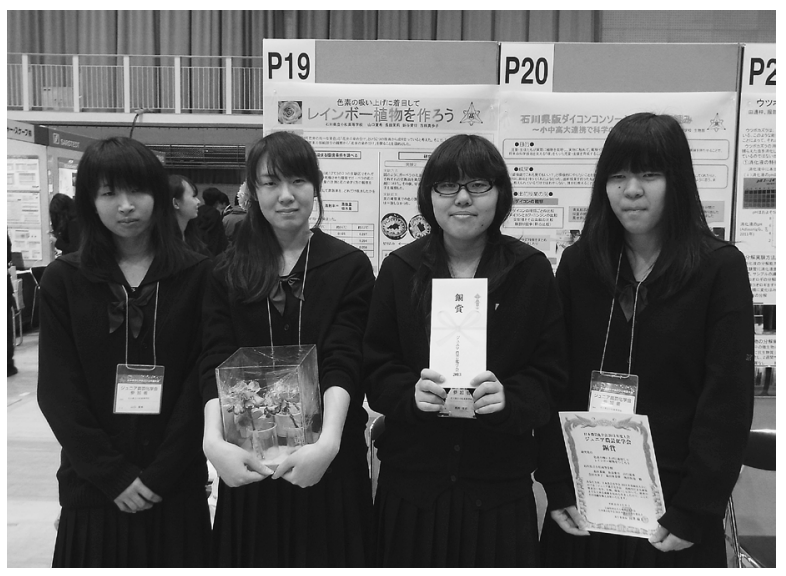

写真 1 - 表彰ポスター（P19）と賞状と一緒に
流通量が少なく輸送の問題もあってあまり市場に出回っ ていない. 発表者らは植物の吸水率・蒸散率に注目し, 身近な材料と設備を使って花弁を均一に染めるための条 件を明らかにしている。また維管束構造を詳細に観察す ることで, 花茎下部の維管束と花弁付近の維管束の配置 が異なること, 花直下の維管束の配置に留意して染色す ることが花弁をきれいに染め分けるためには重要である ことを明らかにしている。目標に向かってそれを解決す るための方法を考元, 計画的かつ継続的な研究を進めて いく姿勢は，研究における基本的な姿勢をうかがわせ る．花弁ごとに染め分けるためには，まだクリアすべき 点が残されているが，本研究をさらに進め，花弁ごとに 染め分ける手法を確立することで，さまざまなレイン ボーフラワーが安価に作成されることを期待したい。

（文責「化学と生物」編集委員） 